\title{
Leadership Strategies in Enhancing Integration of Information and Communication Technology in Teaching and Learning in Public Teachers' Colleges in Moshi District, Tanzania
}

\author{
Stanley Luvanda $^{1 *} \quad$ Prof. Prof. Evans Ogoti Okendo (Ph.D.) ${ }^{2} \quad$ Rev. Dr. Peter Siamoo ${ }^{3}$ \\ 1.Masters' Student, Mwenge Catholic University, P.O Box 1226, Moshi-Tanzania \\ 2.Director of Postgraduate Studies, Mwenge Catholic University, P.O Box 1226, Moshi-Tanzania \\ 3.Lecturer, Mwenge Catholic University, P.O Box 1226, Moshi-Tanzania
}

\begin{abstract}
This study was conducted to investigate the leadership strategies in enhancing the integration of information and communication technology in teaching and learning of public teachers' colleges in Moshi district, Tanzania. The study was guided by Transformational Leadership Theory developed in 1978 by James McGregor Burns. The study employed a mixed research approach under which a convergent research design was used. The target population of the study was 03 public teachers' college 03 principals, 103 teacher educators, and 768 teacher trainees which make the total population of 874. Probability sampling of simple random sampling and stratified sampling techniques was used to determine the study sample. Questionnaires and an Interview Guide were used as instruments for data collection. The reliability of quantitative instruments was established through Cronbach Alpha; ( $r=0.92$ for teacher trainees' questionnaires and $r=0.90$ for teacher educators' questionnaires). The results show that the extent to which leadership strategies in enhancing ICT integration were reflecting on ICT leadership approaches of ICT modeling, supporting with ICT facilities, inspiring, and evaluating the integration of ICT were positively responded by teacher educators and teacher trainees which conform with transformational leadership theory. However, other leadership strategies in enhancing ICT integration on ICT practices such as team working, encouraging ICT use, motivating, and empowering use of ICT in teaching and learning were responded contrarily by teacher educators and teacher trainees. Because of the variation of responses from teacher trainees to teacher educators, the study concluded that the extent to which the role of leadership strategies used to enhance the integration of ICT in teaching and learning was less effective. The study recommends that principals' capacity building through seminars and workshops especially on transformational and technological leadership skills could help to improve management teams' practices to enhance the integration of ICT in teaching and learning among teacher educators and teacher trainees.
\end{abstract}

Keywords: ICT Integration, Leadership strategies, Teaching and learning, Teachers' College.

DOI: $10.7176 / \mathrm{JEP} / 12-32-11$

Publication date: November $30^{\text {th }} 2021$

\section{Introduction}

Enhancing ICT integration in teaching and learning in an educational institution is challenging and it requires perseverance from every member of an institution, it requires the intervention of educational leaders to play their roles effectively. The leadership strategies under this study refer to the practices which are considered as the most significant aspects of enhancing ICT integration in teaching and learning within educational institutions. According to Malcolm (2017), all the practices undertaken by heads of educational institutions are known as transformational leadership practices, which prominently work well in enhancing the integration of ICT in teaching and learning. Polizzi (2011) emphasized that leadership practices play an important role in enhancing the integration of ICT into teaching and learning just because it can foster the use of ICT at a strategic and action level.

According to Carinand Guvhu (2018)transformational leader always models, encourages, supports, inspires, motivates, and evaluates teaching staff and learners to engage in ICT uses in teaching and learning. The leadership strategies in enhancing the integration of ICT in teaching and learning have been applied by the head educational institution worldwide.

In the USA according to Schoeny (2002), the primary role of the leadership in educational institutions specifically when it comes to the ICT integration into learning is to facilitate the provision of the infrastructure; equipment; time to learn; rewards for application of the materials; support for taking risks; and generally facilitating the individualized learning process required by the enriched opportunities. That is to say, by enhancing the integration of ICT to promote teaching and learning, teachers' colleges should be equipped with adequate ICT facilities and principals should fulfill the responsibilities of motivating teacher educators and teacher trainees upon successful application of the ICT materials toward effective teaching and learning processes.

In Kenya, Macharia \& Pelser, (2014) acknowledge that the characteristics of the chief executive education 
officer play a pivotal role in the diffusion and infusion of technology in a higher education institution. This might be the same as in the teacher education context, where the principals in the teachers' college should have technology use behaviors to influence others to employ the use of the technology in teaching and learning. Therefore, the college principals are viewed as the changing agents to teacher educators and teacher trainees on the integration of ICT to improve the teaching and learning process. Also to exercise leadership in ICT integration, principals should be knowledgeable and experts in the effective and efficient use and integration of ICT into the college curriculum.

In Tanzania, about the 2000s the preparation of heads of education institutions focused on pedagogical and instructional leadership. Onguko et al. (2008), suggests that the preparation of educational leadership should involve the technological aspect of leadership, where principals are given opportunities to use technology in learning of different aspects and are expected to apply skills and knowledge in their respective educational institutions to improve teaching and learning process. Therefore, principals are expected to use the acquired skills and knowledge to reward others "primary adopters", and act as a blueprint of the changing process, and well as supporting others in the usage of ICT to improve the teaching and learning process. However, the current status of the role of leadership strategies in enhancing the integration of ICT in teaching and learning in public teachers' colleges was thoroughly investigated, to provide answers on the magnitude of the role of leadership strategies on effective enhancing ICT integration to improve teaching and learning

According to Afshari et al. (2012), the leadership strategies observed in enhancing ICT integration in teaching and learning in educational institutions were seen as part and parcel of the principals' responsibilities. For this reason, principals in teachers' colleges need to be equipped with the knowledge and skills of leadership strategies to enable them to bring an impact in enhancing ICT among teacher educators and teacher trainees. To effectively be in a position to enhance ICT in teaching and learning in teachers' colleges, principals should exercise leadership strategies to the college community in accomplishing different teaching and learning tasks. Moreover, practicing leadership strategies in ICT thoroughly will allow the adoption and integration of ICT to be effective among teacher educators and teacher trainees. How well the principals exercise leadership strategies with the rest of the team, determines the success in the integration of ICT in teaching and learning among teacher educators and teacher trainees. However, it has been reported by Prospero (2013) that team members are not supported when using ICT in teaching and learning in teachers' colleges. Such a situation should not be neglected because it might result in degrading on the quality of graduated teachers from the teachers' colleges hence the poor quality of teacher education. Therefore, the current study provides information on the extent to which the leadership strategies are undertaken to enhance ICT integration in teaching and learning in public teachers' colleges in Moshi district, Tanzania.

\section{Statement of the Problem}

Even though the government took efforts to train thoroughly all principals on different strategies of enhancing and managing ICT in the teaching and learning process Kisanjara et al. (2014). However, according to Swarts \& Wachira (2010), it appears that there was no strategic approach to the integration of ICT in the education system holistically, which lead to the unending complaints community on the range of leadership strategies in enhancing the integration of ICT to improve teaching and learning processes in the teachers' colleges. For a quite long time, it has been a national requirement that all educational institutions should effectively manage and enhance the incorporation of ICT to improve the quality of the teaching and learning process (MoEVT, 2007). However, the support for the implementation of ICT in teacher education is weak and needs strengthening(Swarts \& Wachira 2010). Therefore, it spiked a desire to know the extent to which the leadership strategies were exercised in enhancing ICT integration to improve teaching and learning among teachers' colleges in the Moshi district.

Studies like that of Kisanjara et al. (2014), Prospero (2013), and Nchahoruri \& Mungwabi (2015)Francis (2017), Kayombo \& Mlyakado (2016), Kihoza et al. (2016), and Ngeze, (2017) focused much on the significance of integrating ICT in the curriculum, management, and administration also factors used in enhancing ICT integration in teaching and learning in secondary schools and teachers' colleges in Tanzania. However, none of the reviewed studies have examined the leadership strategies in enhancing ICT integrations in teaching and learning in public teachers' colleges. Therefore, this study has investigated the leadership strategies in enhancing ICT integration in teaching and learning in public teachers' colleges in Moshi district, Tanzania.

\section{Significance of the Study}

The findings of the study have deepened the understanding of the education on the role of leadership strategies in enhancing the integration of ICT to improve the quality of the teaching and learning process. The study has identified essential elements that have usefulness in enhancing integration ICTs to promote the quality of teacher education.

The study findings have provided information that is useful to the Ministry of Education Science and Technology by pointing out gaps existing in leadership practices in enhancing the effective integration of ICT in 
teaching and learning in educational institutions of Tanzania.

Furthermore, the study has generated knowledge (in education administration) that may help teachers' colleges principals on the effective leadership practices that might help to enhance the integration of ICT to improve teaching and learning among their followers. Also generated knowledge might be used by other researchers for references concerning leadership strategies in enhancing ICT integration in teaching and learning in different educational institutions, hence the quality of education in general.

\section{Theoretical Framework}

This study is guided by Transformational leadership theory. The transformational leadership theory was developed in 1978 by James McGregor Burns. Transformational leadership theory is all about leadership that creates positive change for the followers, whereby followers take care of each other's interests and act in the interests of the group as a whole. It focuses on how leaders can create positive change in their followers by creating a high-performance workforce to work beyond their task requirements. This theory encourages leaders to demonstrate authentic strong leadership with the idea that employees will be inspired to follow suit.

Transformational leadership enhances the motivation, morale, and performance of followers through a variety of mechanisms. These mechanisms include practices such as modeling the way, inspiring a shared vision, enabling others to act, and encouraging the act.

Modeling the way comprises the earning correct and esteem to lead through individual involvement and action directly. The first thing an educational transformational leader does is to establish principles concerning the way people (subordinates, teachers, board members, students, colleagues alike) should follow and be guided to pursue and achieve an institutional goal. Under this part of education, a transformational leader articulates the values, morals, and beliefs. In modeling the way the voice to share a unique vision of a leader is used rather than sharing ideas and vision of others because "people follow first the person, then the plan" (Townley, 2009).

Inspiring a shared vision is the second mechanism that is necessary for bringing together all human entities within an institution to foster a commitment to an expected shared future and not just the present. Transformational leaders are expected to believe they can make a difference passionately. To demonstrate longterm values within an institution, a transformational educational leader shares vision through enlisting others. Transformational education leaders use the power and energy to motivate and inspire those who are around them, so those people around them should do the same in the name of a shared vision.

The third mechanism is enabling others to act, fosters collaboration and teamwork spirits. It involves encouraging people to work together in learning communities and empowering individuals to succeed. Transformational leaders are expected in enabling those around them to take the initiative with a spirit of collaboration and development. They endeavor to create an environment of trust and human dignity and to help each person within an institution concerning individual needs and interests to let them develop a sense of ownership and responsibility within an organization.

The last mechanism is encouraging the act, which is about supporting individuals and groups to achieve their vision. To achieve organizational goals people, need encouragement and motivation; leaders expect highly from the employees and themselves. By influencing motivation and encouragement, transitional leader attaches rewards and celebrate every winning of other members in an organization, as they need to share the rewards of their efforts.

\subsection{Strength of the Transformational Leadership Theory}

Transformational leadership theory is relevant to this study in the sense that, it provides teachers' college administrators with practices that act as practical guidance on the adoption of ICT to improve teaching and learning in their respective educational institutions. The theory proposes for the effective enhancement of ICT integration in teaching and learning processes, teachers' college administrators should involve leadership strategy by modeling to others ICTs in performing daily activities.

It has been said that leaders should demonstrate the values of integrating ICT in teaching and learning, by applying the personal values to the working environment so as help teacher educators and teacher trainees to arrive at an understanding of the guiding principles on the integration of ICT in teaching and learning and follow them.

Then through inspiring shared vision, the theory emphasizes partnership strategy for the effective enhancement of ICT in teaching and learning. As the theory suggests, it has been said college administrators, should inspire a shared vision of integrating ICT as proposed in education policy, to bring a new paradigm of integration of ICT in teaching and learning.

Furthermore, it contributes to the study through the practice of enabling others to act. The practice reflects the role of capacity-building strategy because enabling others involves encouraging people to work together and empowering capacity building and training of teacher educators and teacher trainees about the integration of ICT in teaching and learning. 
It has been said that administrators in teachers' colleges are required to initiate by supporting good ideas from the experienced of other educational institutions; those ideas of effectively integrating ICT in teaching and learning and encourage followers to adopt in their practices. The theory suggests that leaders should commit themselves to search for opportunities from other educational institutions, design a means for individual teacher educators and teacher trainees to change, to grow, and to improve their respective practices through the integration of ICT.

\subsection{Weaknesses of Transformational Leadership Theory}

The weakness of the transformational leadership theory assumes that all leaders have the same kind and level of behaviors in influencing their followers to the effective and efficient adoption of ICT in teaching and learning. It has ignored the role of the behavioral quality of the head of an institution, for example, the theory is quite to the influence of personal behaviors of the administrators. On the other side, people do resist changes in the adoption of ICT in teaching and learning within an institution, the theory assumes that all people under teachers' colleges will always agree and be motivated all the time when their leader shares their thoughts with them. Therefore, the theory does not hint out what steps to be taken to enhance the integration of ICT in teaching and learning.

Also, transformational leadership theory does not indicate the precise duration for effective leadership to influence the integration of ICT in teaching and learning. Education leaders and followers indeed share their dreams by working together through different strategies to achieve a common goal of integration of ICT in teaching and learning. But sometimes the management plans might be long-term plans in which people might work with ICT for long hours which leads to tiredness and dissatisfaction among learners, the theory does not give an alternative to what should be done.

\subsection{Justification of the Theory}

Regardless of the weakness that the transformational leadership theory has, remains to be the best theory to be used as it focuses on the variables. ICT integration in teaching and learning in the colleges should be planned and managed with the best practices. To be specific as all stated in the theory are said to be practiced by the colleges' leaders, through modeling, supporting, guiding, encouraging, and rewarding the college community; in turn, tend to integrate ICT in the teaching and learning process. Furthermore, the integration of ICT in teaching and learning might help improve the quality of teacher education because ICT is useful in planning, assessment, and evaluation.

\section{Literature Review}

The main scope of a literature review of the study was to focus on empirical studies related to the leadership strategies on enhancing integration of ICT in teaching and learning in educational institutions. In this section, empirical studies have been put into the theme as per the research question.

Yamamoto \& Yamaguchi (2019)conducted a study on relationships between ICT implementation in schools and factors related to transformational leadership: A case of primary school in Mongolia. The study employed a survey design under quantitative design whereby questionnaires were administered to 222 school leaders. The study found that the component of inspirational motivation is especially important for ICT use in classroom teaching. Also, the study found out that teachers' collaborations that stimulate innovation are associated with both teachers' ICT use in teaching, and funding allocation for ICT training. The study conforms with the transformational leadership theory which guides the current study that the leadership strategies of inspiration and motivation are essentials in enhancing the integration o ICT in teaching and learning educational institutions. However, the study involved heads of institutions only, without the involvement of learners and teaching staff which signifies that the study might be biased by having a single-sided perception of the problem. Therefore, the current study gathered data from both learners, teaching staff, and leaders purposely for triangulation of the information collected and having a broad perception of the problem. the investigate further the extent to which leadership strategies enhance the integration of ICT in teaching and learning in public teachers' colleges in Moshi district, Tanzania.

In Malaysia, Thannimalai and Raman (2018) conducted a study on the principals' technology leadership and teachers' technology integration in the 21 st-century classroom. The study engaged a cross-sectional survey design using a quantitative method to answer the research questions, whereby questionnaires were administered to 90 principals and 645 teachers of the secondary schools. The study determined that the Malaysian secondary school's principals' levels of technological leadership are high and implied that there is a significant relationship between principals' technological leadership and teachers' technology integration in the classroom. The study confirms that leadership strategies in technology are the potential factors in enhancing the integration of ICT in teaching and learning within educational institutions. Therefore, the current study has used different approaches of convergent design to collect both quantitative and qualitative data to investigate the extent to which leadership enhances the integration of ICT in teaching and learning. Under which questionnaires and interview guide were 
used as instruments for data collection.

Furthermore, Guvhu (2018) conducted a study to assess the roles of principal's leadership on the effective integration of information and communication technologies for teaching and learning in Zimbabwe. The study employed a sequential explanatory mixed-methods research design whereby the demographic and Likert scale questionnaires were administered to the 280 principals as participants of the quantitative research phase. For the qualitative research phase, a researcher used documentary and focused group interviews were conducted with 10 principals. The study found out the eight leadership roles that linking with the integration of ICT in teaching and learning are, creating corroborative teams, empowering staff members, setting direction, developing staff, redesigning the organization, defining the school mission, and creating a positive culture. Also, the studies found out there are three leadership practices that support the integration of ICT in teaching and learning; distribute leadership practice, transformational leadership practice, and pedagogical leadership practices. The research findings show that to promote effective integration of information and communication technology in teaching and learning; leadership plays a major role. However, by using a convergent design under a mixed approach the current study has investigated the extent to which leadership strategies enhance the integration of ICT in teaching and learning among public teachers' colleges found in the Moshi district.

Nang'unda (2019) conducted a study to assess principals' leadership in information communication technology integration in public secondary school management in Bungoma County, Kenya. The study adopted a descriptive survey and correlational research designs. Interview schedule, observation checklist, and document analysis guide were used as instruments of data collection to 245 deputy principals, 82 principals, 123 directors of studies, and 359 class teachers. The research findings conclude that the principals' technology leadership strategies were more pronounced in infrastructural changes than organizational and policy and cultural changes. The study emphasizes the significance of technology leadership strategies in enhancing the integration of ICT in teaching and learning. However, the study findings do not establish the extent to which leadership strategies enhance ICT integration in teaching and learning. Therefore, the current study has investigated the extent to which leadership strategies enhance the integration of ICT in teaching and learning in Public teachers' colleges in the Moshi district.

Francis (2017) conducted a study assessing the head of schools' competence for leadership of ICT integration in Tanzania secondary schools: a case of selected secondary schools in Kinondoni municipality. The study employed a convergent mixed research design under a mixed research approach. The data collection instruments involved were questionnaires, interviews, documentary review, and observation checklist. The study found out that the heads of schools were less competent in the use of ICT for teaching and learning activities, that why professional development training should be conducted. Also, the head of schools had limited understanding of the integration of ICT in teaching and learning activities and few heads of schools participated in ICT professional development programs. The study, therefore, leaves a gap by focusing on secondary schools only and the focus was to assess the competence of ICT leadership among heads of secondary schools without hinting more details on how ICT leadership will enhance ICT integration in the teaching and learning process. Therefore, to fill the gap the current study has assessed the extent to which technology leadership strategy enhances the integration of information and communication technology in teaching and learning in public teachers' colleges in Moshi District, Tanzania.

The reviewed empirical study has shown the importance of leadership strategies in enhancing ICT integration in teaching and learning within educational institutions. The effective strategies for effective adoption of ICT in teaching and learning were inspiration, motivation (Yamamoto \& Yamaguchi 2019), empowering staff members, setting direction, developing staff, redesigning the organization, defining the school mission, and creating a positive culture(Guvhu 2018 and Nang'unda, 2019). Furthermore, the study has shown that some heads of education institutions are less competent in leading the integration of ICT in their respective institutions(Francis 2017). To fill this gap, therefore the current study was conducted to investigate the extent to which leadership strategies enhance the integration of ICT in teaching and learning in Public teachers' colleges.

\section{Methodology}

The study employed a convergent design under a mixed-method approach. According to Creswell and Creswell (2018) under convergent research design, the researcher gathers both quantitative and qualitative data, analyzes both datasets separately, compares the results from the analysis of both datasets, and interprets as to whether the results support each other. The researcher mixed the two databases by merging the results during interpretation to ensure the two data sets conform. Convergent design helped in interpreting the findings of two databases to see if there is a convergence between two sources of information.

In this study, the target population involved three public teachers' colleges found in the Moshi district. Where the cadre that involved were principals, teacher educators, and teacher trainees who are by were involved in teaching and learning activities. From principals in teachers' colleges, the target population of this study constituted 3 principals, 103 teacher educators, and 768 teacher trainees that make a total population of 874 in 
public teachers' colleges found in the Moshi district. The methods of sampling which were used to select sample representativeness were stratified sampling and simple random sampling. Stratified sampling was used to group teacher trainees and teacher educators into two strata of males and females. Simple random sampling was used to select participants from both strata and principals to arrive at the sample of 2 principals, 40 teacher educators, and 169 teacher trainees.

The instruments administered to collect data were a questionnaire for teacher trainees and teacher educators and an interview guide for principals. The reliability of quantitative data was established through Cronbach Alpha; ( $\mathrm{r}=0.92$ in questionnaire for teacher trainees and $\mathrm{r}=0.90$ from the questionnaire for teacher educators) while the reliability for the qualitative data was established through respondent validation and triangulation of data. The quantitative data collected were coded, entered into the computer then analyzed into percentages and frequencies. The qualitative data collected was analyzed by coding contents into themes.

\section{Findings and Discussion}

The study aimed to determine the extent to which leadership strategy enhances the integration of information and communication technology in teaching and learning in public teachers' colleges in the Moshi district, Tanzania. Questionnaires' responses for teacher trainees and teacher educators are summarized in table 1 and table 2 respectively.

Data in table 1 indicate that simple majority $(66 \%)$ of teacher trainees who participated in the study have the positive view that the principals and teacher educators are their models in using ICT during teaching and learning (Mean = 3.72). Also, the same idea of the principals and teacher educators being models to their followers had been supported by the principal during interviews, as they agree to use ICT devices to perform different tasks which in turn influence others to impersonate the ICT usage in teaching and learning. As principals one indicated that:

I use devices for personal and administrative tasks; generally, I use ICT devices to communicate with my workers through WhatsApp and emails. For instance, if someone what to seek permission and he/she is not around we communicate through emails to pass information. Also, it happens usually that I want to provide some directives to the staff members I use email. (Interview, 03rd July 2021).

This implies that for the successful integration of ICT is important for college principals who should model the use of ICT to teacher educators and if the modeling is successful then teacher educators may model the use of ICT to the teacher trainees. The findings support that of Guvhu (2018) that the principals should be competent role models in ICTs so that their followers would emulate them. Where, through regular emulating from principals and teacher educators who are responsible for teaching and learning process, hence aid in enhancing ICT integration in teaching and learning. Modeling was used as the leadership strategy to influence the followers in enhancing ICT integration in teaching and learning.

Furthermore, data in table 1 indicate that majority (52\%) of the teacher trainees had a negative opinion on the fact that the college supports them to access the internet during teaching and learning $($ mean $=2.59)$, while minority $(36 \%)$ of the teacher trainees supported positively. However, during an interview session principal agreed on the responsibility of facilitating ICT integration in teaching and learning that, "....my role is to find the fund to acquire necessary teaching and learning ICT facilities and guide the effective use of available ICT facilities through proposed guidelines" (Interview, 03rd July 2021).

It implies that even though college principals strive to improve the teaching and learning environment which favors the integration of ICT, but teacher trainees do not cherish the colleges' efforts to ensure there is a satisfactory provision of internet services. This is an indication that for teachers' colleges to enhance effective integration of ICT in teaching and learning, the principals should support teacher trainees to access the internet to interact with different online materials as well and different teaching and learning techniques.

Data in table 1 indicate that minority $(42 \%)$ of the teacher trainees perceived negatively the role that principal works with teacher trainees to ensure ICT integration in teaching and learning is in a safe, ethical and legal manner (Mean $=2.95)$, while only minority $(40 \%)$ of the teacher trainees responded positively. This implies that teacher trainees and teacher educators have low esteem toward working with the principals as college leaders to ensure ICT integration in teaching and learning in a safe, ethical and legal manner. It implies that the principals do not work in harmony with teacher trainees to inspire them in enhancing ICT integration in teaching and learning is in a safe, legal, and ethical way. This is conflicting with the findings of Yamamoto \& Yamaguchi (2019) that principals' collaborations stimulate innovation which is associated with both teachers' and learners' ICT use in teaching and learning. 
Table 2: Responses of Teacher Trainees on the extent to which leadership strategies enhances the integration of ICT

\begin{tabular}{|c|c|c|c|c|c|c|c|c|c|c|c|c|}
\hline \multirow[t]{2}{*}{$\mathbf{S} / \mathbf{N}$} & \multirow[t]{2}{*}{ Statements } & \multicolumn{2}{|c|}{$\begin{array}{c}\text { Strong } \\
\text { Disagree }\end{array}$} & \multicolumn{2}{|c|}{ Disagree } & \multicolumn{2}{|c|}{ Neutral } & \multicolumn{2}{|c|}{ Agree } & \multicolumn{2}{|c|}{$\begin{array}{c}\text { Strong } \\
\text { Agree }\end{array}$} & \multirow[t]{2}{*}{ Mean } \\
\hline & & $\mathrm{f}$ & $\%$ & $\mathrm{f}$ & $\%$ & $\mathrm{f}$ & $\%$ & $\mathrm{f}$ & $\%$ & $\mathrm{f}$ & $\%$ & \\
\hline i. & $\begin{array}{l}\text { The principal and teacher educators are } \\
\text { our models in using ICT during } \\
\text { teaching and learning. }\end{array}$ & 8 & 5 & 14 & 8 & 36 & 21 & 71 & 42 & 40 & 24 & 3.72 \\
\hline i. & $\begin{array}{l}\text { The college supports us to access the } \\
\text { internet during teaching and } \\
\text { learning. }\end{array}$ & 72 & 43 & 15 & 9 & 22 & 13 & 35 & 21 & 25 & 15 & 2.59 \\
\hline i. & $\begin{array}{l}\text { The principal works with teacher } \\
\text { trainees to ensure ICT integration } \\
\text { in teaching and learning is in a } \\
\text { safe, ethical and legal manner. }\end{array}$ & 46 & 27 & 25 & 15 & 30 & 18 & 37 & 22 & 31 & 18 & 2.95 \\
\hline$r$ & $\begin{array}{l}\text { The principal and teacher educators } \\
\text { encourage teacher trainees to make } \\
\text { changes by integrating ICT to } \\
\text { improve teaching and learning. }\end{array}$ & 10 & 6 & 15 & 9 & 64 & 38 & 42 & 25 & 38 & 22 & 3.49 \\
\hline r. & $\begin{array}{l}\text { The principal and teacher educators } \\
\text { encourage teacher trainees to } \\
\text { integrate ICT in teaching to } \\
\text { increase equity, inclusion, and } \\
\text { equality in education. }\end{array}$ & 7 & 4 & 12 & 7 & 71 & 42 & 44 & 26 & 35 & 21 & 3.52 \\
\hline i. & $\begin{array}{l}\text { The principal and teacher educators } \\
\text { motivate teacher trainees to use } \\
\text { ICT in performing different } \\
\text { teaching activities that improve } \\
\text { teaching and learning. }\end{array}$ & 49 & 29 & 20 & 12 & 20 & 12 & 41 & 24 & 39 & 23 & 3.01 \\
\hline i. & $\begin{array}{l}\text { Teacher trainees are empowered to use } \\
\text { ICT in innovative ways to create a } \\
\text { culture of using ICT in teaching } \\
\text { and learning. }\end{array}$ & 12 & 7 & 62 & 37 & 27 & 16 & 38 & 22 & 30 & 18 & 3.07 \\
\hline i. & $\begin{array}{l}\text { Teacher trainees are supported in using } \\
\text { ICT to improve teaching and } \\
\text { learning and to meet diverse } \\
\text { teaching demands. }\end{array}$ & 46 & 27 & 21 & 12 & 21 & 12 & 47 & 28 & 34 & 20 & 3.01 \\
\hline x. & $\begin{array}{l}\text { The principal and teacher educators } \\
\text { always inspire teacher trainees to } \\
\text { be innovative to create a } \\
\text { conducive learning environment } \\
\text { that allows the integration of ICT. }\end{array}$ & 4 & 2 & 56 & 33 & 35 & 21 & 36 & 21 & 38 & 22 & 3.28 \\
\hline x. & $\begin{array}{l}\text { The principal and teacher educators } \\
\text { always evaluate teacher trainees' } \\
\text { progress of the integration of ICT } \\
\text { in teaching and learning. }\end{array}$ & 8 & 5 & 19 & 11 & 26 & 15 & 78 & 46 & 38 & 22 & 3.70 \\
\hline & Grand Mean & & & & & & & & & & & 3.23 \\
\hline
\end{tabular}

Furthermore, data in table 1 indicate that simple minority (47\%) of the teacher trainees have a positive judgment on the practices played by the principals and teacher educators to encourage teacher trainees to make changes by integrating ICT to improve teaching and learning (mean $=3.49)$, compared to great minority $(15 \%)$ of teacher trainees who had a negative view on the particular issue. This indicates that teacher trainees favor being encouraged by the principals and teacher educators to make changes in teaching and learning through using ICT, which implies that for an effective enhancement of ICT integration in teaching and learning the leaders should encourage their followers to use ICT in teaching and learning continuously. The findings agree with the Transformational leadership theory as described by Yamamoto \& Yamaguchi (2019) that encouragement is among the leadership practices that when performed effectively, enhances the adoption of technology use in teaching and learning.

Data from table 1 show that minority $(47 \%)$ of the teacher trainees have a positive view on the behaviors of 
the principals and teacher educators used to motivate them to use ICT in performing different teaching activities that improve teaching and learning; while minority $(41 \%)$ of the teacher trainees perceived negatively $(\mathrm{mean}=$ 3.01). This is an indication that teacher trainees favor being motivated to use ICT in teaching and learning. It implies that principals, as well as teacher educators, have to play a great role to motivate teacher trainees to continue to show a desirable behavior of integrating ICT in teaching and learning. It reflects with results found in Mongolia Yamamoto \& Yamaguchi (2019) that principals as transformational leaders should encourage innovation in education practices by motivating their followers.

Also, Data in Table 2 indicated that simple majority $(58 \%)$ of the teacher educators supported that their principals use digital (ICT) tools in official communication with members of the college community (Mean = $3.18)$, while great minority $(25 \%)$ of the teacher educators responded negatively. This implies that the principals in teachers' colleges set as good examples in using ICT in their respective colleges to the extent that educators learn by replicating and contextualizing the use of ICT in teaching and learning. For instance, principals' usage of ICT in communication to the members of the college community or staff, repeatedly staffs' responses of using the same media of communication led to mastering ICT usage in teaching and learning. As one principal explained during an interview session that: for my position, I use ICT facilities to perform most of the administrative activities and by doing so, forces other members to respond to the order or directives that have been given to them in the same way. (Interview, 09th July 2021)

Also, results in table 2 indicate that simple majority (55\%) of the teacher educators have neutral responses whether the principals always ensure that teacher educators have access to the internet to be used for teaching and learning purposes (Mean $=2.60)$. While only minority $(15 \%)$ of teacher educators responded positively to the fact of the college supports to access the internet during teaching and learning. However, one principal indicated that: ...I have a role to ensure the availability and maintenance of ICT gadgets ready for use in teaching and learning in the college. (Interview, 09th July 2021).

It is an indication that principals used to provide ICT facilities but neglect to provide support for internet services which is an essential tool in enhancing ICT integration among teacher educators. Failure to support the provision of the internet tends to demoralize the tendency of integrating ICT in teaching and learning among teacher educators and teacher trainees. This finding conflicting with that of Nang'unda (2019) that the principal's leadership approach in enhancing ICT use in teaching and learning was more pronounced in infrastructural changes than organizational, policy, and culture changes. Support in provision of the internet services in teachers' colleges favors interaction with online materials in different formats such as documents, audio, and video which are necessary for improving teaching and learning.

Furthermore, data in table 2, minority $(45 \%)$ of the teacher educators were neutral to respond that principals always work with teacher educators to ensure ICT integration in teaching and learning is safe, ethical, and legal. (Mean $=2.80)$. While minority $(28 \%)$ of teacher educators responded positively and $28 \%$ responded negatively to the statement that principals always work with teacher educators to ensure ICT integration in teaching and learning is safe, ethical, and legal. This implies that principals' strategy of cooperating with teacher educators was unknown to the majority of the teacher educators. This is contradicting with the findings of Yamamoto \& Yamaguchi (2019) that principals' collaborations stimulate innovation which is associated with both teachers' and learners' ICT use in teaching and learning. Collaboration among principals and teacher educators intended to work together with ICT to solve the problem concerning teaching and learning tasks. Collaborative problemsolving practices arouse newness in the application of ICT to improve teaching and learning. 
Table 3: Responses of Teacher Educators on the extent to which leadership strategies enhances the integration of ICT

\begin{tabular}{|c|c|c|c|c|c|c|c|c|c|c|c|c|}
\hline \multirow[t]{2}{*}{$\mathrm{S} / \mathrm{N}$} & \multirow[t]{2}{*}{ Statements } & \multicolumn{2}{|c|}{$\begin{array}{c}\text { Strong } \\
\text { Disagree }\end{array}$} & \multicolumn{2}{|c|}{ Disagree } & \multicolumn{2}{|c|}{ Neutral } & \multicolumn{2}{|c|}{ Agree } & \multicolumn{2}{|c|}{$\begin{array}{l}\text { Strong } \\
\text { Agree }\end{array}$} & \multirow[t]{2}{*}{ Mean } \\
\hline & & $\mathrm{f}$ & $\%$ & $\mathrm{f}$ & $\%$ & $\mathrm{f}$ & $\%$ & $\mathrm{f}$ & $\%$ & $\mathrm{f}$ & $\%$ & \\
\hline i. & $\begin{array}{l}\text { The principal uses digital (ICT) tools in } \\
\text { official communication with members of } \\
\text { the college community. }\end{array}$ & 8 & 20 & 2 & 5 & 7 & 18 & 21 & 53 & 2 & 5 & 3.18 \\
\hline ii. & $\begin{array}{l}\text { The principal always ensures that teacher } \\
\text { educators have access to the internet to be } \\
\text { used for teaching and learning purposes. }\end{array}$ & 11 & 28 & 1 & 3 & 22 & 55 & 5 & 13 & 1 & 3 & 2.60 \\
\hline iii. & $\begin{array}{l}\text { The principal always works with teacher } \\
\text { educators to ensure ICT integration in } \\
\text { teaching and learning is safe, ethical, and } \\
\text { legal. }\end{array}$ & 9 & 23 & 2 & 5 & 18 & 45 & 10 & 25 & 1 & 3 & 2.80 \\
\hline iv. & $\begin{array}{l}\text { The principal always encourages teacher } \\
\text { educators to use ICT to improve teaching } \\
\text { and learning. }\end{array}$ & 12 & 30 & 3 & 8 & 12 & 30 & 8 & 20 & 5 & 13 & 2.78 \\
\hline v. & $\begin{array}{l}\text { The principal encourages teacher } \\
\text { educators to integrate ICT in teaching to } \\
\text { increase equity, inclusion, and equality in } \\
\text { education. }\end{array}$ & 3 & 8 & 13 & 33 & 15 & 38 & 6 & 15 & 3 & 8 & 2.83 \\
\hline vi. & $\begin{array}{l}\text { The principal motivates tutors to use ICT } \\
\text { in performing different teaching activities } \\
\text { that improve teaching and learning. }\end{array}$ & 19 & 48 & 5 & 13 & 5 & 13 & 9 & 23 & 2 & 5 & 2.25 \\
\hline vii. & $\begin{array}{l}\text { The principal empowers teacher educators } \\
\text { to use ICT in innovative ways to create a } \\
\text { culture of using ICT in teaching and } \\
\text { learning. }\end{array}$ & 2 & 5 & 21 & 53 & 5 & 13 & 12 & 30 & 0 & 0 & 2.68 \\
\hline viii. & $\begin{array}{l}\text { The principal supports teacher educators } \\
\text { in using ICT to improve teaching and } \\
\text { learning to meet diverse teaching } \\
\text { demands. }\end{array}$ & 11 & 28 & 3 & 8 & 8 & 20 & 17 & 43 & 1 & 3 & 2.85 \\
\hline ix. & $\begin{array}{l}\text { The principal always inspires teacher } \\
\text { educators to be innovative to create a } \\
\text { conducive learning environment that } \\
\text { allows the integration of ICT. }\end{array}$ & 6 & 15 & 10 & 25 & 8 & 20 & 11 & 28 & 5 & 13 & 2.98 \\
\hline $\mathrm{x}$. & $\begin{array}{l}\text { The principal always evaluates teacher } \\
\text { educators' progress in the integration of } \\
\text { ICT in teaching and learning. }\end{array}$ & 5 & 13 & 4 & 10 & 10 & 25 & 20 & 50 & 1 & 3 & 3.20 \\
\hline & Grand Mean & & & & & & & & & & & 2.81 \\
\hline
\end{tabular}

On the other hand, data in table 2 show that minority (41\%) of teacher educators disagree with the fact that the principal encourages teacher educators to integrate ICT in teaching to increase equity, inclusion, and equality in education, while only minority $(23 \%)$ agree on a particular action. It implies that teacher educators reflect their experience on the discouragement from their principals when integrating ICT in teaching and learning, which might deteriorate all the efforts of integration of ICT existing among teacher educators. The findings conflicting with that of Yamamoto \& Yamaguchi (2019) that principals as transformational leaders should encourage innovation in education practices by motivating their followers in equal ways. Equal reassuring of all followers might reassure the achievement of the institutional objectives of using ICT facilities to improve teaching and learning.

Also, data in table 2 indicate that majority (61\%) of teacher educators have negative responses on the behaviors of the principals to motivate them to use ICT in performing different teaching activities that improve teaching and learning $($ mean $=2.25)$; while minority $(28 \%)$ of the teacher educators responded positively on a particular task. This implies teacher educators were not persuaded with the ways principals as their leaders motivate them when they use ICT in performing different teaching activities. Lack of motivation among teacher educators demoralized all the efforts of integration of ICT in teaching and learning, which might also affect the integration of ICT to their learners.

Both data in Table 1 and table 2; show that teacher trainees and teacher educators have more items that 
reflect positively on the practices of leadership strategy in enhancing ICT integration in teaching and learning to the respective grand means scores of 3.23 and 2.81. This implies that the majority of the teacher trainees and teacher educators agreed that different practices undertaken by principals as part of a leadership strategy are essential in enhancing ICT integration in teaching and learning in their respective teachers' colleges. The extent, to which leadership strategies are undertaken among teacher trainees and teacher educators, is a good motive for effective integration of ICT in teaching and learning hence provision of quality education in teachers' colleges. This is because, through the guidance of the Transformational Leadership Theory principals' guidance, support, encouragement, inspiration, and motivation in using ICT; teacher trainees or teacher educators become better in the integration of ICT in teaching and learning. By integrating ICT in teaching and learning, teacher trainees can lead to effective learning and teaching hence improvement in the quality of education.

Table 4: Verbatim quotations coded into themes

\begin{tabular}{|c|c|c|}
\hline Transcripts (Verbatim Quotes) & Code & Themes \\
\hline \multirow{4}{*}{$\begin{array}{l}\text { Most of the time, I use devices for personal and administrative tasks; generally, I use ICT } \\
\text { devices to communicate with my workers through WhatsApp and emails. For instance, if } \\
\text { someone what to seek permission and he/she is not around we communicate through } \\
\text { emails to pass information. Also, it happens usually that I want to provide some } \\
\text { directives to the staff members I use emails. There are different ICT devices available in } \\
\text { my institution used for teaching and learning purposes as a principal. Therefore, as } \\
\text { principal, I have a role to ensure the availability and maintenance of ICT gadgets ready } \\
\text { for use in teaching and learning in the college } \\
\text { To achieve the vision as principal, my role is to find the fund to acquire necessary } \\
\text { teaching and learning ICT facilities and guide the effective use of available ICT facilities } \\
\text { through proposed guidelines. The guidelines established or all, teacher trainees and } \\
\text { teacher educators to follow. Also, for my position of principal; I use ICT facilities to } \\
\text { perform most of the administrative activities and by doing so, forces other members to } \\
\text { respond to the order or directives that have been given to them in the same way }\end{array}$} & UID1 & $\begin{array}{c}\text { Modeling } \\
\text { the ICT } \\
\text { usage }\end{array}$ \\
\hline & RoP2 & \\
\hline & RoP1 & \\
\hline & 2 & $\begin{array}{c}\text { Modeling } \\
\text { the ICT } \\
\text { usage }\end{array}$ \\
\hline
\end{tabular}

Keys: UID and UID2 = principals' usage of ICT devices through modeling strategy

RoP1 and RoP2 = roles played by principals to enhance ICT integration in teaching and learning

\section{Conclusions and Recommendations}

Basing on the findings a study concluded that the extent to which leadership strategies used to enhance the integration of ICT in teaching and learning vary from teacher trainees' to teacher educators' perspectives. Most teacher trainees were found to be influenced by the principals' leadership approaches of modeling, encouraging, motivating, supporting, and inspiring in enhancing ICT integration in teaching and learning. On other hand, teacher educators were objective to the principals' roles of modeling, supporting, inspiring, and evaluating in enhancing the ICT integration in teaching and learning. That is to say, principals' leadership strategies of encouraging and motivating teacher educators have been observed to be less significant compared to that of teacher trainees in enhancing the integration of ICT in teaching and learning. That means principals' leadership strategies on enhancing ICT in teaching and learning should focus much on encouraging and motivating teacher educators and teacher trainees to use ICT facilities in performing teaching and learning tasks.

Furthermore, principals were not supportive to both, teacher trainees and teacher educators specifically on the access to the internet which is considered as the most important service required in enhancing the integration of ICT in teaching and learning in teachers' colleges. This in turn demoralized the behaviors of integration of ICT in teaching and learning existing among teacher educators and teacher trainees. Also, principals' failures to empower innovative skills to teacher educators and teacher trainees were considered to be the reason for having such disparities in several practices which enhance ICT integration in teaching and learning in teachers' colleges in the Moshi district. The findings revealed the extent to which leadership strategies enhance the integration of ICT in teaching and learning in public teachers' colleges in the Moshi district, range from principals' obligations to practices of the procurement, guidance, and maintenance of the ICT facilities as well as encouraging, inspiration, motivation, supporting, and empowering their followers in integrating ICT in teaching and learning. Basing on the conclusions, the study recommends the following: for effective execution of leadership strategies to enhance the integration of ICT in teaching and learning; the principals should be transformational, where the issues of transparency and fair treatment are emphasized. Transformation leaders always work with the followers beyond their self-interest to identify the needed changes in enhancing the integration of ICT in teaching and learning. Under principals' behaviors of transformation leadership, teacher educators and teacher trainees, are expected to be encouraged, motivated, inspired, empowered, and supported fairly on ICT usage. Those kinds of leaders; approaches tend to rise the willingness to use ICT facilities in teaching and learning. Also, researchers recommend that principals should be trained to improve the transformational leadership and technological leadership competency and high competency in using ICT in teaching and learning should be considered in 
vetting for the principal position.

\section{References}

Afshari, M., Bakar, K. A., Luan, W. S., \& Siraj, S. (2012). Factors affecting the transformational leadership role of principals in implementing ICT in schools. Turkish Online Journal of Educational Technology, 11(4), $164-176$.

Caridi, A. A. (2009). The impact of school leadership upon the successful integration of ICT across the curriculum in secondary schools (Issue August).

Creswell, J. W., \& Creswell, D. J. (2018). Research Design Qualitative, Quantitative, and Mixed Methods Approaches (Fifth Edit). SAGE Publications Inc.

Francis, F. (2017). The head of schools' competence for leadership of ICT integration in Tanzania secondary schools: a case of selected secondary schools in Kinondoni municipality. University of Dar es salaam.

Guvhu, R. (2018). Principal leadership and the integration of information and communication technologies for teaching and learning in Zimbabwe. In The university of the free state (Issue April).

Kayombo, J. J., \& Mlyakado, B. P. (2016). The paradox of ICT integration in secondary education in Tanzania : Assessment of teachers ' ICT knowledge and skills in Tanga and Mwanza regions. International Journal of Research Studies in Educational Technology, 5(1), 17-27.

Kihoza, P., Kihoza, P., Zlotnikova, I., Bada, J., \& Kalegele, K. (2016). Classroom ICT integration in Tanzania: Opportunities and challenges from the perspectives of TPACK and SAMR models. International Journal of Education and Development Using ICT, 12(1).

Kisanjara, S. B., Mangula, M., \& Noyi, S. (2014). ICT application in teaching and learning processes by tutors : a case of two selected tanzania teachers colleges. Global Journal of Engineering, Design and Technology, $3(1), 12-17$

Macharia, J. K. N., \& Pelser, T. G. (2014). Key factors that influence the diffusion and infusion of information and communication technologies in Kenyan higher education. Studies in Higher Education, 39(4), 695-709. https://doi.org/10.1080/03075079.2012.729033

Malcolm, D. B. (2017). Leadership in information technology: Leadership theories, perspectives and ethical dilemmas. The Siegel Institute Journal of Applied Ethics, 2(1). https://doi.org/10.32727/21.2018.2

MoEVT. (2007). Information and communication technology (ICT) policy for basic education. In Ministry of education and vocational training.

Nang'unda, K. A. (2019). Assessment of principals' leadership in information communication technology integration in public secondary schools management in Bungoma County, Kenya. https://repository.maseno.ac.ke/handle/123456789/1373

Nchahoruri, J. F., \& Mungwabi, H. (2015). Factors constraining effective application of icts in teachers' training colleges in tanzania. University of Dar Es Salaam Library Journal, 1(2011), 53-70. https://journals.udsm.ac.tz/index.php/lj/article/view/83

Ngeze, L. V. (2017). ICT integration in teaching and learning in secondary schools in Tanzania: readiness and way forward. International Journal of Information and Education Technology, 7(6). https://doi.org/10.18178/ijiet.2017.7.6.905

Onguko, B., Abdalla, M., \& Webber, C. F. (2008). Mapping principal preparation in Kenya and Tanzania. Journal of Educational Administration, 46(6), 715-726. https://doi.org/10.1108/09578230810908307

Polizzi, G. (2011). Measuring School Principals 'Support for ICT Integration in Palermo , Italy. Journal of Media Literacy Education, 2(3), 113-122.

Prospero, D. (UDOM). (2013). The challenges in the application and communication of ICT in TCs in Mwanza and Shsinyanga regions. The University of Dodoma.

Schoeny, Z. G. (2002). Leadership of information technology in education. Journal of Information Technology for Teacher Education, 11(3), 245-252. https://doi.org/10.1080/14759390200200135

Swarts, P., \& Wachira, M. E. (2010). Tanzania: ICT in education situational analysis. Global E-Schools and Communities Initiative, July, 1-67.

Thannimalai, R., \& Raman, A. (2018). Principals technology leadership and teachers technology integration in the 21st century classroom. International Journal of Civil Engineering and Technology, 9(2), 177-187.

Townley, C. (2009). The innovation challenge : Transformational leadership in technological university libraries. IATUL Proceedings.

Yamamoto, Y., \& Yamaguchi, S. (2019). Relationships between ICT Implementation at Schools and Factors Related to Transformational Leadership: A Case of primary school in Mongolia. International Journal of Education and Development Using Information and Communication Technology (IJEDICT), 15(2), 45-61. https://sustainabledevelopment.un.org/?menu=1300' 